\title{
Turmeric and Vitamin E on the Performance and Quality of Eggs from White Layers
}

\section{Christine Laganá1* (D), Erika S. P. Braga Saldanha1, José Roberto Sartori², Elisabeth Gonzales², Renato Luis Luciano ${ }^{3}$, Greice Zanatta ${ }^{3}$, Vitor Barbosa Fascina ${ }^{2}$}

\footnotetext{
${ }^{1}$ Agência Paulista de Tecnologia dos Agronegócios, Polo Regional do Leste Paulista and UPD Brotas, Secretariat of Agriculture and Supply to the State of São Paulo (SAA), Monte Alegre do Sul, Brazil

${ }^{2}$ Faculty of Veterinary Medicine and Zootechnics, State University of São Paulo, Botucatu Campus, Botucatu, Brazil

${ }^{3}$ Advanced Center for Poultry Agribusiness Technological Research of the Biological Institute (SAA), Descalvado, Brazil

Email: *christine@apta.sp.gov.br
}

How to cite this paper: Laganá, C., Saldanha, E.S.P.B., Sartori, J.R., Gonzales, E. Luciano, R.L., Zanatta, G. and Fascina, V.B. (2019) Turmeric and Vitamin $\mathrm{E}$ on the Performance and Quality of Eggs from White Layers. Agricultural Sciences, 10, 720-726.

https://doi.org/10.4236/as.2019.106056

Received: February 22, 2019

Accepted: June 10, 2019

Published: June 13, 2019

Copyright $\odot 2019$ by author(s) and Scientific Research Publishing Inc. This work is licensed under the Creative Commons Attribution International License (CC BY 4.0).

http://creativecommons.org/licenses/by/4.0/

\section{cc) (i) Open Access}

\begin{abstract}
A 112-day experiment was conducted to evaluate turmeric and vitamin E levels on the productive performance and quality of hen eggs. A total of 432 20-week-old white layers were used, distributed in an entirely randomized design, in a $4 \times 3$ factor scheme (turmeric extract levels and vitamin E levels), with 6 repetitions of 6 birds per cage. The treatments consisted of four levels of turmeric extract inclusion $(0 ; 0.1 ; 0.2$ and 0.3$)$ and three levels of vitamin $\mathrm{E}$ inclusion (0; 50 and $100 \mathrm{IU} / \mathrm{kg})$. Egg quality was evaluated at each 28-day cycle through the variables specific gravity, yolk percentage, albumen percentage, shell percentage and thickness, Haugh unit, yolk index and staining, and production performance: weight, egg production and mass, feed intake, feed conversion $(\mathrm{kg} / \mathrm{kg} ; \mathrm{kg} / \mathrm{dz})$, and mortality. The addition of vitamin $\mathrm{E}$ alone worsened feed intake, egg weight and feed conversion of layers. Turmeric added to $100 \mathrm{IU}$ of Vit E improved egg mass indices, Haugh Unit and yolk index and intensified yolk staining. The amount of turmeric used in this experiment was not sufficient to improve the performance or egg quality of the birds.
\end{abstract}

\section{Keywords}

Plant Extracts, Productive Performance, Phytogenic Additives

\section{Introduction}

In the commercial posture chain, a great diversity of production systems is found to meet the needs of the market, since the consumer has become increasingly aware of the importance of the relationship between diet and health, 
which has encouraged researchers and the food industry to develop products enriched with nutrients capable of producing beneficial effects on health.

There has been progress in research aimed at including viable alternative products, such as plant extracts and vitamins, in the diet of layers, which have been shown to have antimicrobial and antioxidant action and promote improvements in animal performance.

Curcumin, the main bioactive component of saffron, has anti-inflammatory, antioxidant, hepatoprotective, antiviral, anti-carcinogenic and hypolipidemic effects [1]. Due to its biological properties, saffron presents itself as a potential substitute for antibiotics that promote growth.

The knowledge and understanding of the levels of incorporation of natural antioxidants in layer feed, as well as the reaction mechanisms and control forms for them, are of great economic importance for the food industry.

The objective was to evaluate the effect of turmeric powder and vitamin $\mathrm{E}$ levels on the performance and quality of eggs from light white layers at 20 weeks.

\section{Material and Methods}

A total of 432 light layers, Hissex White line 20 weeks old, housed in production cages (100 cm long, $45 \mathrm{~cm}$ high and $45 \mathrm{~cm}$ deep) with independent front feeders and nipple drinkers were used. The light program adopted was 17 hours daily.

The experimental design was entirely randomized, in a $4 \times 3$ factorial (turmeric levels $\times$ vitamin $\mathrm{E}$ levels), totaling twelve combinations with 6 repetitions of 6 birds each. The treatments consisted of four levels of turmeric rhizome powder inclusion ( $0 ; 0.1 ; 0.2$ and 0.3$)$ and three levels of vitamin $E$ inclusion ( 0 ; 50 and $100 \mathrm{IU} / \mathrm{kg}$ ) mixed with a basal ration. The birds received water and feed at will during the entire experimental period, which was composed of four cycles of 28 days each. All rations used were isoenergetic, isoproteic and isoaminoacidic, formulated based on corn, soybean meal and wheat according to the nutritional recommendations proposed by [2] for the laying phase and differed only in relation to the addition of supplementary vitamin $\mathrm{E}$ and turmeric extract.

The maximum and minimum temperatures were measured with the help of a mini data logger located in a central point of the aviary and were recorded daily at 8 o'clock. The mean temperatures were $22.37^{\circ} \mathrm{C} \pm 2.73^{\circ} \mathrm{C}$ and $15.22^{\circ} \mathrm{C} \pm$ $4.98^{\circ} \mathrm{C}$ for maximum and minimum, respectively. Daily mortality data and the number of whole and broken eggs collected were recorded in a proper form. The birds were fed twice a day and during the day the feeders were homogenized several times.

Feed intake (g/bird/day), feed conversion $(\mathrm{kg} / \mathrm{dz})$, daily egg production (\%/bird/day), mean egg weight (g), egg mass (g/bird/day) and egg mass conversion $(\mathrm{kg} / \mathrm{kg})$ were evaluated. At the end of each trial period, the quality of the eggs was assessed by breaking two eggs from each plot. Each egg was weighed individually to record yolk and albumen weights. Specific gravity; percentage of 
yolk, albumen and shell; thickness of shell; Haugh Unit; yolk index and yolk staining through the colorimetric range were verified. Then, the shells were dried in drying ovens at $105^{\circ} \mathrm{C}$ for 3 hours and weighed to determine the weight and percentage of the shell.

The results were tabulated and analyzed by analysis of variance (ANAVA) of the General Linear Model (GLM) procedure with the help of the SAS statistical program [3] and when significant, the means between treatments were compared by the Tukey test at $5 \%$ probability.

\section{Results and Discussion}

\subsection{Performance}

[4] concluded in their study that egg production increased $(\mathrm{P}<0.05)$ with the addition of turmeric powder to laying hen diets. According to the authors, turmeric can improve the performance of the digestive tract in laying hens, resulting in improved egg production. [5] showed that turmeric affected egg production, but not egg weight.

In this study, regardless of the addition of turmeric to the feed, in relation to the control group not supplemented, a negative effect of the addition of vitamin $\mathrm{E}$ in $100 \mathrm{IU} / \mathrm{kg}$ of feed was observed (Table 1) on feed intake, egg weight and feed conversion. Lower feed intake was attributed to the detrimental effect of extra vitamin E supplementation on egg weight and feed conversion results. However, the inclusion of vitamin $\mathrm{E}$ in the $50 \mathrm{IU} / \mathrm{kg}$ feed did not affect the results of

Table 1. Effect of turmeric levels $(0 ; 0.1 \% ; 0.2 \%$ and $0.3 \%)$ and vitamin $\mathrm{E}(0 ; 50$ and $100 \mathrm{IU} / \mathrm{kg})$ on the performance of 20-week-old light white layers.

\begin{tabular}{|c|c|c|c|c|c|c|c|}
\hline $\begin{array}{l}\text { vitamin E } \\
(\mathrm{IU} / \mathrm{kg})\end{array}$ & $\begin{array}{l}\text { feed intake } \\
\text { (g/bird/day) }\end{array}$ & $\begin{array}{c}\text { egg production } \\
(\%)\end{array}$ & $\begin{array}{l}\text { egg weight } \\
\text { (g) }\end{array}$ & $\begin{array}{l}\text { egg mass } \\
(\mathrm{g})\end{array}$ & $\begin{array}{l}\text { feed conversion ratio } \\
\text { (kg feed/dozen egg) }\end{array}$ & $\begin{array}{l}\text { feed conversion } \\
\text { ratio ( } \mathrm{g} \text { feed/g egg) }\end{array}$ & $\begin{array}{l}\text { viability } \\
\text { (\%) }\end{array}$ \\
\hline 0 & 104.38 & 96.98 & $57.85 \mathrm{~A}$ & 56.20 & 1.29 & $1.86 \mathrm{~B}$ & 99.87 \\
\hline 50 & $103.98 \mathrm{AB}$ & 95.68 & $57.07 \mathrm{~A}$ & 55.41 & 1.29 & $1.88 \mathrm{~B}$ & 100.00 \\
\hline 100 & $101.57 \mathrm{~B}$ & 97.04 & $54.90 \mathrm{~B}$ & 52.51 & 1.28 & $1.94 \mathrm{~A}$ & 99.87 \\
\hline \multicolumn{8}{|l|}{ turmeric (\%) } \\
\hline 0 & 102.91 & 95.53 & 56.74 & 54.99 & 1.27 & 1.87 & 99.94 \\
\hline 0.1 & 103.18 & 97.16 & 56.41 & 54.22 & 1.29 & 1.91 & 99.94 \\
\hline 0.2 & 103.00 & 96.95 & 56.56 & 55.04 & 1.27 & 1.88 & 99.83 \\
\hline 0.3 & 104.15 & 96.63 & 56.74 & 54.58 & 1.30 & 1.91 & 99.94 \\
\hline \multicolumn{8}{|c|}{ P-value } \\
\hline vitamin $\mathrm{E}$ & 0.019 & 0.115 & $<0.001$ & $<0.001$ & 0.562 & $<0.001$ & 0.209 \\
\hline turmeric & 0.719 & 0.223 & 0.793 & 0.505 & 0.178 & 0.089 & 0.547 \\
\hline vit $\mathrm{E} \times$ turmeric & n.s & n.s & n.s & 0.043 & n.s & n.s & n.s. \\
\hline CV (\%) & 3.51 & 2.60 & 2.06 & 3.40 & 3.45 & 3.10 & $0, .29$ \\
\hline
\end{tabular}

Means followed with different letters on the line differ from each other by the Tukey test $(\mathrm{P}<0.05)$. 
these variables when compared to the negative control. Excess vitamin E in the feed may have caused saturation in the intestinal absorption mechanisms resulting in low feed efficiency.

For the variable egg mass, there was significant interaction of vitamin E vs. turmeric supplementation, obtaining the worst results when $100 \mathrm{IU} / \mathrm{kg}$ of vitamin $\mathrm{E}$ was added at any level of turmeric inclusion (Table 2). Although not significantly different from control $(P>0.05)$, the lower egg mass result with 100 IU/kg supplementation of vitamin E suggests that the negative effect was exacerbated when turmeric was added. This phytogen has in its composition substances with antioxidant action similar to vitamin E, causing, perhaps, a typical toxicity situation of excess intake of fat-soluble vitamins.

[6] observed that the addition of extra vitamin E and turmeric supplementation to layer feed did not affect the performance of layers. But there was a significant improvement in intake when the feed was added only with $1 \%$ turmeric. In the present study, the highest level of turmeric used was $0.3 \%, 70 \%$ lower than that reported by the cited authors. Therefore, the turmeric levels used here, regardless of the inclusion of vitamin $\mathrm{E}$, were considered insufficient to obtain positive results similar to those reported by the authors. However, the association of $100 \mathrm{IU} / \mathrm{kg}$ of vitamin E with low levels of turmeric inclusion $(0.1 \%$ to $0.3 \%$ ) was considered inadequate for laying hens because it impairs egg mass.

When subjected to heat stress, laying hens [7] and quails [8] [9] supplemented with $250 \mathrm{mg} / \mathrm{Kg}$ of vitamin E presented adverse effects of stress on egg production and mass. In the same context, [10] supplemented the layer feed with $60 \mathrm{IU}$ vitamin $\mathrm{E}$ and observed positive effects on feed intake and egg production. It is therefore assumed that only under stressful conditions is extra vitamin E supplementation beneficial and necessary.

Regarding the supplementation of turmeric extract, regardless of the inclusion of vitamin E, no effect was observed on the performance of laying hens at peak posture.

The absence of significant influence of phytogenic sources of antioxidants (annato, turmeric, oregano) on the performance of layers is a fact already proven in other studies [1] [11] [12].

Table 2. Interaction of levels of turmeric powder $(0 ; 0.1 ; 0.2$ and $0.3 \%)$ and vitamin $\mathrm{E}(0$; 50 and $100 \mathrm{IU} / \mathrm{kg}$ ) for the variable egg mass of white commercial layers at 20 weeks.

\begin{tabular}{ccccc}
\hline \multirow{2}{*}{ vitamin E (IU/kg) } & \multicolumn{4}{c}{ turmeric (\%) } \\
\cline { 2 - 5 } & \multicolumn{4}{c}{ Egg Mass (g) } \\
\cline { 2 - 4 } 0 & 56.83 & $55.52 \mathrm{~A}$ & $56.75 \mathrm{~A}$ & $55.72 \mathrm{~A}$ \\
50 & 54.03 & $55.56 \mathrm{~A}$ & $55.49 \mathrm{AB}$ & $56.55 \mathrm{~A}$ \\
100 & 54.13 & $51.57 \mathrm{~B}$ & $52.87 \mathrm{~B}$ & $51.45 \mathrm{~B}$ \\
\hline
\end{tabular}

Upper case letters in the column and lower case letters in the row differ from each other by Tukey's test (P $<0.05)$. 
However, for broilers, [13] observed an improvement in performance when they supplemented $0.50 \%$ of turmeric to the baseline diet. The authors attributed this effect to the presence of active compounds of turmeric that stimulate the antioxidant activity and the synthesis of proteins of the enzymatic system of the bird.

\subsection{Egg Quality}

No significant difference was observed between the treatments regarding the specific gravity of the eggs and the percentages of yolk, albumen and shell. However, considering the isolated effect of vitamin $\mathrm{E}$, the values of Haugh unit (HU) and yolk index (YI) differed significantly (Table 3).

The eggs of the birds fed with the feed with the highest level of vitamin E presented the best results of HU and YI than the other treatments that did not differ significantly from each other. [10] did not observe significant changes in the yolk index, regardless of the thermal stress applied or the level of vitamin E supplementation, however the authors stated that 60 and $120 \mathrm{IU}$ of vitamin E / kg of feed for birds exposed to heat stress was sufficient to improve the Haugh units to a level similar to that of birds supplemented with $20 \mathrm{IU}$ of vitamin E / kg of feed in thermoneutral environments.

The high HU values observed are related to the age of the birds. Eggs from young hens usually have higher HU values than eggs from older hens, regardless of diet. The HU values of the eggs analyzed in this experiment are in the range of

Table 3. Effect of turmeric levels $(0 ; 0.1 \% ; 0.2 \%$ and $0.3 \%)$ and vitamin E $(0 ; 50$ and 100 $\mathrm{IU} / \mathrm{kg}$ ) on the quality of eggs from 20 -week-old white layers.

\begin{tabular}{|c|c|c|c|c|c|c|c|}
\hline $\begin{array}{l}\text { Vitamin E } \\
(\mathrm{IU} / \mathrm{kg})\end{array}$ & $\begin{array}{l}\text { specific } \\
\text { gravity }\end{array}$ & $\begin{array}{l}\text { yolk } \\
\text { color }\end{array}$ & $\begin{array}{l}\text { Yolk } \\
(\%)\end{array}$ & $\begin{array}{c}\text { Albumen } \\
(\%)\end{array}$ & $\begin{array}{c}\text { shell } \\
(\%)\end{array}$ & $\begin{array}{c}\text { Haugh } \\
\text { unit }\end{array}$ & yolk index \\
\hline 0 & 1.095 & 5.00 & 26.13 & 63.94 & 9.92 & $90.95 \mathrm{~B}$ & $0.43 \mathrm{~B}$ \\
\hline 50 & 1.099 & 5.13 & 25.99 & 64.05 & 9.96 & $91.75 \mathrm{~B}$ & $0.43 \mathrm{~B}$ \\
\hline 100 & 1.096 & 5.54 & 25.81 & 64.19 & 9.99 & $92.20 \mathrm{~A}$ & $0.44 \mathrm{~A}$ \\
\hline \multicolumn{8}{|l|}{ turmeric (\%) } \\
\hline 0.0 & 1.095 & 5.12 & 25.83 & 64.21 & 9.96 & 91.25 & 0.43 \\
\hline 0.1 & 1.099 & 5.24 & 25.96 & 64.08 & 9.96 & 92.25 & 0.43 \\
\hline 0.2 & 1.096 & 5.30 & 25.83 & 64.21 & 9.97 & 92.00 & 0.43 \\
\hline 0.3 & 1.095 & 5.25 & 26.31 & 63.75 & 9.95 & 91.03 & 0.43 \\
\hline \multicolumn{8}{|c|}{ P-value } \\
\hline vit $E$ & 0.28 & $<0.001$ & 0.35 & 0.57 & 0.42 & 0.04 & $<0.001$ \\
\hline turmeric & 0.52 & 0.07 & 0.20 & 0.27 & 0.99 & 0,10 & 0.32 \\
\hline vit $\mathrm{E} \times$ turmeric & 0.36 & $<0.001$ & 0.92 & 0.86 & 0.46 & 0.96 & 0.16 \\
\hline CV (\%) & 1.41 & 6.72 & 5.17 & 2.18 & 3.40 & 3.24 & 3.06 \\
\hline
\end{tabular}

Means followed by different letters in the column differ from each other by the Tukey test $(\mathrm{P}<0.05)$. 
Table 4. Deployment of the interaction between vitamin E and turmeric powder for the yolk color variable of egg from white commercial layers at 20 weeks of age.

\begin{tabular}{ccccc}
\hline & \multicolumn{4}{c}{ yolk color turmeric (\%) } \\
\hline Vitamin E (IU/kg) & 0 & 0.1 & 0.2 & 0.3 \\
\hline 0 & 5.06 & $4.93 \mathrm{~B}$ & $4.94 \mathrm{~B}$ & $5.07 \mathrm{~B}$ \\
50 & 5.08 & $5.26 \mathrm{AB}$ & $5.18 \mathrm{~B}$ & $5.00 \mathrm{~B}$ \\
100 & $5.22 \mathrm{~b}$ & $5.53 \mathrm{Aab}$ & $5.76 \mathrm{Aa}$ & $5.65 \mathrm{Aa}$ \\
\hline
\end{tabular}

Upper case letters in the column and lower case letters in the row differ from each other by Tukey's test (P $<0.05)$.

90, independent of the diets used, indicating excellent quality.

There was no isolated effect of turmeric powder, disagreeing with [11], who obtained positive effects of turmeric supplementation observed in laying hens, which presented higher egg production, higher shell weight, higher percentage of yolk, higher fertility and hatchability, when compared with the control.

There was significant interaction for yolk color (Table 4). The inclusion of turmeric was more efficient as a gem dye when it was included in the diet 100 (IU/kg) of vitamin E.

[1] observed a greater presence of white color in the egg yolks when they replaced $50 \%$ of the corn from the layer diet by sorghum and used $2 \%$ of dry turmeric rhizome. Also [14] concluded that dry turmeric rhizome was not a good pigment for quail egg yolk staining.

\section{Conclusions}

The addition of vitamin $\mathrm{E}$ alone worsens feed intake, egg weight and feed conversion of layers. Added turmeric to $100 \mathrm{IU}$ vitamin E helps improve egg mass indices, Haugh unit and yolk index and intensify yolk staining.

Although studies have shown beneficial effects of turmeric/curcumin, the results obtained with the use of turmeric in laying diets were not promising. It is possible that the low bioavailability of curcumin as well as the low concentrations of turmeric rhizome used in this study may have limited the scope of the results. Therefore, further studies are needed to evaluate higher concentrations of turmeric in the diet, as well as to improve the bioavailability of the plant.

\section{Conflicts of Interest}

The authors declare no conflicts of interest regarding the publication of this paper.

\section{References}

[1] Laganá, C., Pizzolante, C.C., Saldanha, E. and Moraes, J.E. (2011) Turmeric Root and Annato Seed in Second-Cycle Layer Diets: Performance and Egg Quality. Brazilian Poultry Science, 13, 171-176.

https://doi.org/10.1590/s1516-635x2011000300002

[2] Rostagno, H.S., Albino, L.F.T., Donzele, J.L., Gomes, P.C., Oliveira, R.F., Lopes, D. 
C. and Euclides, R.F. (2011) Tabelas brasileiras para aves e suínos: composição de alimentos e exigências nutricionais de aves e suínos. $3^{\text {a }}$ Edition, UFV, Viçosa, MG. https://doi.org/10.1590/s1516-35982007001000027

[3] SAS Institute (2002) SAS Start User's Guide, Version 9. SAS Intitute Inc., Cary, NC.

[4] Malekizadeh, M., Moeini, M.M. and Ghazi, S.H. (2012) The Effects of Different Levels of Ginger (Zingiber officinale Rosc) and Turmeric (Curcuma longa Linn) Rhizomes Powder on Some Blood Metabolites and Production Performance Characteristics of Laying Hens. Journal Agricultural Science Technology, 14, 127-134. https://doi.org/10.5897/jmpr11.1316

[5] Park, S.S., Kim, J.M., Kim, E.J., Kim, H.S., Kim, B. and Kang, C.W. (2012) Effects of Dietary Turmeric Powder on Laying Performance and Egg Qualities in Laying Hens. Korean Journal Poultry Science, 39, 27-32.

https://doi.org/10.5536/kjps.2012.39.1.027

[6] Radwan, N.L., Hassan, E.M.Q. and Fayek, H.M. (2008) Effect of Natural Antioxidant on Oxidative Stability of Eggs and Productive and Reproductive Performance of Laying Hens. International Journal of Poultry Science, 7, 134-150. https://doi.org/10.3923/ijps.2008.134.150

[7] Bollengier-Lee, S., Williams, P.E. and Whitehead, C.C. (1999) Optimal Dietary Concentration of Vitamin E for Alleviating the Effect of Heat Stress on Egg Production in Laying Hens. British Poultry Science, 40, 102-107. https://doi.org/10.1080/00071669987917

[8] Sahin, K., Sahin, N. and Onderci, M. (2002a) Vitamin E Supplementation Can Alleviate Negative Effects of Heat Stress on Egg Production, Egg Quality, and Digestibility of Nutrients and Egg Yolk Mineral Concentrations of Japanese Quails. Research in Veterinary Science, 72, 307-312. https://doi.org/10.1016/s0034-5288(02)00126-1

[9] Sahin, K., Kucuk, O., Sahin, N. and Mustafa, S. (2002b) Effects of Vitamin C and E on Lipid Peroxidation Status, Serum Hormone, Metabolite, and Mineral Concentrations of Japanese Quails Reared under Heat Stress $\left(34^{\circ} \mathrm{C}\right)$. Vitamin and Nutrition Research, 72, 91-100. https://doi.org/10.1024/0300-9831.72.2.91

[10] Kirunda, D., Scheideler, S.E. and McKee, R. (2001) The Efficacy of Vitamin E (DLalpha-Tocopheryl Acetate) Supplementation in Hen Diets to Alleviate Egg Quality Deterioration Associated with Temperature Exposure. Poultry Science, 80, 1378-1383. https://doi.org/10.1093/ps/80.9.1378

[11] Radwan, N.L., Hassan, R.A., Qota, E.M. and Fayek, H.M. (2008) Effect of Natural Antioxidant on Oxidative Stability of Eggs and Productive and reproductive Performance of Laying Hens. International Journal of Poultry Science, 7, 134-150. https://doi.org/10.3923/ijps.2008.134.150

[12] Zhao, X., Yang, Z.B., Yang, W.R., Wang, Y., Jiang, S.Z. and Zhang, G.G. (2011) Effects of Ginger Root (Zingiber officinale) on Laying Performance and Antioxidant Status of Laying Hens and on Dietary Oxidation Stability. Poultry Science, 90, 1720-1727. https://doi.org/10.3382/ps.2010-01280

[13] Raghdad, A. and Al-Jaleel, A. (2012) Use of Turmeric (Curcuma longa) on the Performance and Some Physiological Traits on the Broiler Diets. The Iraqi Journal of Veterinary Medicine, 36, 51-57.

[14] Silva, W.J., Gouveia, A.B.V.., Souza, F.E., Santos, F.R., Silva, J.M.S. and Minafra, C.S. (2017) Turmeric and Sorghum for Egg-Laying Quails. Italian Journal of Animal Science, 16, 1-9. https://doi.org/10.1080/1828051x.2017.1360160 